\title{
Married Monastics and Military Life: Contradictions and Conflicted Identities within South Korea's Buddhist Chaplaincy System
}

\author{
Kyungrae Kim $₫$ and Cheonghwan Park * \\ Department of Buddhist Studies, Dongguk University, Seoul 04620, Korea; wizkyung@dongguk.edu \\ * Correspondence: avadana@dongguk.edu
}

Received: 13 April 2020; Accepted: 19 May 2020; Published: 21 May 2020

\begin{abstract}
Since its modern origins in the Buddhist Purification Movement of the 1950s, South Korea's Jogye Order has established monastic celibacy as central to its identity and claim to legitimacy as a Buddhist sect. However, in the order's urgency to introduce Buddhist chaplains to the South Korean military in the 1960s, after almost two decades of Protestant monopoly over the chaplaincy program, the Jogye Order permitted its chaplains to marry; a practice which soon became the norm. This contradiction grew increasingly problematic for the order over subsequent decades and, in 2009, it attempted to resolve the issue by reversing the marriage exception for chaplains, reinforcing their identity as monastics within the order. While controversial, the resolution has proved effective in practice. However, this reversal has also provoked unprecedented lawsuits against South Korea's Ministry of National Defense in 2017 and a ruling by Korea's Human Rights Commission in 2018, challenging the Jogye Order's exclusive control of the military's Buddhist chaplaincies. Given the challenges these issues currently present to the Jogye Order's chaplaincy program, this article interrogates the origins, history, significance, and impact of the issues surrounding the order's marriage exemption for its military chaplains.
\end{abstract}

Keywords: Jogye Order; monastic celibacy; Purification Movement; military chaplains; contemporary Korean Buddhism

\section{Introduction}

Article 20 of the current Republic of Korea (also known as South Korea) constitution grants religious freedom to its citizens and prohibits the state from according privileged status to any religion. In practice, however, only select religious organizations are permitted to participate in the South Korean military's chaplaincy program. In the religiously pluralistic society, competition between various sects within South Korea's religious marketplace can be fierce, and chaplaincy positions offer coveted opportunities for proselytizing among the country's 600,000 active soldiers and three million additional reservists. South Korean military chaplains, in turn, help conscripts emotionally endure the rigors of military life and legitimize mandatory military service as a force for the greater good. In principle, the military's chaplaincy program is open to any religion. However, participating organizations must first navigate political hurdles and extensive bureaucracy while demonstrating that their doctrines and practices are compatible with military objectives, effectively limiting involvement to only the country's largest religions (Tikhonov 2015, p. 10).

Launched during the Korean War (1950-1953), South Korea's military chaplaincy program was monopolized by the Protestant clergy for almost two decades. However, in the late 1960s, Buddhist chaplains were introduced to the armed forces, and the Jogye Order (K. Jogyejong, hereafter "JO"), the largest of more than 250 Korea's Buddhist sects, was granted exclusive control of the program's 
ecclesiastical management. To qualify as chaplains, the order's gunseung, or "military monks," must complete the requisite four years of Buddhist University education, followed by additional months of training at a South Korean military academy, before being commissioned as lieutenant or captain in the Army, Navy, or Air Force (Ministry of National Defense 2016a, 2016b). With 134 active chaplains, the JO celebrated the 50th anniversary of its Buddhist chaplaincy program in 2018. ${ }^{1}$ Largely heralded a success, the program is regarded as crucial to the order's proselytization efforts. However, it has also generated contradictions which have become problematic for the order over recent decades. Interestingly, JO chaplains generally do not perceive any incongruities between traditional Buddhist prohibitions against violence and military service, which is unavoidable for South Korean men see (Tikhonov 2015, pp. 14-15). Rather, since the inception of its chaplaincy program, the JO has granted chaplains leniency in following their monastic precepts, and while monastic celibacy is one of the ideological cornerstones of the order, for many decades it became normal, if not expected, for its chaplains to marry.

In an effort to rectify the issue, in 2009 , the JO passed a resolution reestablishing celibacy as mandatory for monastics entering its chaplaincy program. However, the resolution incited further controversy, highlighting incongruities between the military and religious hierarchies to which the order's chaplains are accountable. It also provoked two unprecedented lawsuits against South Korea's Ministry of National Defense (K. Gukbangbu, hereafter "MND") in 2017 and a ruling by Korea's Human Rights Commission in 2018, challenging the order's monopolization of the Buddhist chaplaincy program. Given the challenges these issues currently present to the JO's chaplaincy program, this article interrogates the origins, significance, and impact of the issues surrounding the JO's marriage exemption for its chaplains. It begins by surveying the modern origins of the JO within the acrimonious schism of the "Purification Movement" over the issue of monastic celibacy, before briefly examining the history of the order's chaplaincy program. In Section 4, the article explores in detail the issues surrounding the marriage exemption granted by the JO to its chaplains, followed by the revocation of the exemption in 2009 as well as the lawsuits and further challenges this reversal has presented. It concludes with a discussion of the overall impact and future implications of the JO's efforts to end the marriage exception for its chaplains.

\section{The Purification Movement and Jogye Order Identity}

Introduced in the fourth century C.E., Buddhism thrived on the Korean Peninsula for over a millennium as a state religion patronized by a succession of kingdoms. However, with the ascendency of the Neo-Confucian Joseon Dynasty (1392-1910), Buddhism was progressively stripped of its wealth and privilege as prominent temples were disbanded and monastics banned from entering cities. Surviving monastics retreated to remote mountain temples where Buddhism was "virtually quarantined" for 500 years, supported largely by the peasantry (Buswell 1992, p. 23; 1996). This institutional suppression was finally lifted in 1895. However, subsequent efforts to reform and modernize Korean Buddhism coincided with the growing Japanese influence on the peninsula, which culminated in Japan's formal annexation of Korea in 1910. Although many turn-of-the-century Korean Buddhist reformers looked to Japanese Buddhism for inspiration, Japanese support for Korean Buddhism "was far from benign" as colonial authorities and Japanese Buddhist missionaries sought to appropriate Korea's indigenous Buddhist institutions for their own purposes (Buswell 1992, p. 24; Tikhonov 2010, p. 270). During this period, many Korean monastics began disregarding their traditional precepts by marrying, eating meat, and drinking alcohol; practices already widely adopted by Japanese Buddhist clerics following the Meiji Restoration in 1868. With the support of the Japanese authorities and several prominent Korean reformers, a council of leading abbots lifted prohibitions against ecclesiastical marriage in 1926,

1 As of April 2018, there were a total of 492 chaplains serving within the South Korean armed forces, including 258 Protestants, 97 Catholics, and three Won Buddhists. 
permitting the wives and families of Korean monastics to reside in Buddhist temples. As noted by scholar Robert Buswell, such "profound changes to Korean monastic life" marked "the end of an era for traditional Korean Buddhism" (Buswell 1992, p. 29). These changes also laid the groundwork for a bitter schism with Korea's monastic community decades later.

During the final years of the Japanese Annexation (1910-1945) the remaining minority of celibate Korean monastics began organizing in opposition to the married clerics, who now outnumbered celibates 10 to one. In 1954, in the aftermath of the Korean War, the celibates launched the "Purification Movement" (K. Jeonghwaundong) to expel the married clergy who had come to dominate the Korean Buddhist community. Portraying themselves as the "true representatives ... of orthodox Korean Buddhist practice," (Buswell 1992, p. 31) the celibate faction denounced the married clergy as Japanese "collaborators," (Park 2007, p. 131) winning the support of South Korean president Syngman Rhee (in office 1948-1960). Beginning in 1954, Rhee issued a series of decrees demanding the resignation of all "Japanized" monks in order who were "deemed collaborators of the Japanese rule." However, married monastics refused to vacate their temples and the struggle between the two factions continued through the decade, becoming increasingly bitter. Legal battles were fought in the courts and National Assembly, while both sides staged sit-ins, protests, and marches. Attempts to occupy temples and expel rival monastics resulted in physical confrontations and even violence. Finally, in 1961, intervention by the newly-established military government of President Chung-hee Park (in office 1962-1979) granted control of the Korean Sangha to the celibate faction. After another decade of litigation over temple ownership, the married clerics officially incorporated their own independent Taego Order (K. Taegojong) in 1970. (For more on South Korea's Buddhist Purification Movement see Kang 2000, pp. 79-112; Park 2007; Mun 2011, pp. 237-368). Maintaining approximately 3000 temples nation-wide, the Taego Order remains the second-largest Buddhist sect in Korea and, in recent decades, has cultivated a growing international presence.

After the schism, the celibate-controlled Jogye Order retained ownership of nearly all the major Buddhist properties in the nation. Overcoming sectarian infighting and geographical isolation in the 1970s, the JO has since grown to become the largest of Korea's Buddhist orders. The order maintains more than 3000 temples, organized within 25 districts and overseen by the JO's central administration in Seoul. JO temples are staffed by approximately 12,000 ordained monastics (K. bigu), almost half of whom are female (K. biguni), who vow to follow the precepts of the Dharmaguptaka Vinaya as well as the "Pure Rules" (K. Baijang jingguei) of Chinese master Baizhang Huaihai (720-814). Beginning with various reform movements in the 1980s, the JO has increased its social activism, media presence, and engagement with secular society. As of the 2005 census, approximately $28 \%$ of South Koreans identified themselves as Buddhists, while the JO itself currently claims around seven million registered lay members. Despite increased involvement with wider society, the JO still defines itself as a monastic-oriented order, placing primacy on monastic discipline, temple rituals, and meditation practice (Kim et al. 2019). Celibacy remains firmly entranced in the order's monastic identity and is enforced through various JO regulations, violation of which is grounds for immediate dismissal from the order. ${ }^{2}$

\section{Korean Buddhist Chaplaincy: Its History and Conflicts ${ }^{3}$}

According to the regulations of South Korea's MND, military chaplains are commissioned officers of the Korean Army holding dual status as staff officers and clergyman. As non-combatants, chaplains have no military command and carry no weapons. They wear military uniforms during working hours

2 See JO Regulation (K. Jogyejongbeop; 조계종법) 3-9, Education Regulations for Novices 5-1 (K. Haengjagyoyukbeop; 행자교육 법), and Monastic Duties (K. Seungnyeobeobuimujohang; 승려법의무조항) 4-32-2.

3 The history of Buddhist chaplaincy summarized in this section is based on The 50 Year History of the Buddhist Chaplain Service (불교군종사: 군승50년사) (Jogye Order 2018). For more details on the history of Buddhist Chaplaincy, see (Kim 2007, pp. 131-75; Ham 2016, pp. 160-75). 
but don religious attire when carrying out ceremonies and educational events, which are held every Sunday and Wednesday. The MND permits participating religious organizations to select their own candidates for the program, which are generally accepted after passing military training requirements for officers. However, the number of chaplains accorded to each organization is subject to nuanced political negotiations determined, in part, by religious demographics and relations between several main religious organizations and the government (Tikhonov 2015, pp. 10-11).

While religion in the South Korean society has traditionally been pluralistic and fluid, the Protestant clergy were granted an exclusive monopoly over the nation's military chaplaincy program for the first 18 years of its history. In February 1951, South Korean president Syngman Rhee, himself a devout Protestant, formally established a chaplaincy program within the ROK armed forces modeled after that of the U.S. military (For more on U.S. military chaplaincy see Brinsfield 2009, pp. 17-24; Waggoner 2019). Although Protestants comprised only 2\% of the South Korean population at the time, their staunch anti-communism made them valued supporters of the fledgling South Korean state while also providing the country with an important link to Christian aid organizations in the United States. In exchange for providing solace and moral training to South Korean soldiers, the majority of whom were forcibly conscripted, Protestant chaplains were granted "privileged access to barrack life." These chaplains, in turn, utilized their positions as missionary tools, winning many life-long converts among young men enduring deprivation, hardship, and the trauma of war. The number of Protestant Evangelicals in South Korea had tripled by 1960 and continued growing exponentially through the 1970s and 1980s; a fact which scholar Vladimir Tikhonov partially attributes to the successful proselytization efforts of these Protestant chaplains (Lee 2019a; Kang 2015, pp. 175-204; 2016, pp. 65-95; Tikhonov 2013, pp. 6-12).

While individual Buddhist temples provided services for Buddhist soldiers during and after the Korean War, due to the sectarian strife of the 1950s (see Section 2 above), the Buddhist community was unable to challenge the Protestant monopoly of the military's chaplaincy program. In 1960, the Jogye Order petitioned South Korea's MND and National Assembly to send Buddhist chaplains to the military but were denied due to the on-going conflict. During the 1960s, the Jogye Order entered into what Tikhonov describes as "a competition of loyalty" with South Korean Protestants, deploying the doctrine of "national-protection Buddhism" (Kr. hoguk bulgyo) and other historical precedents in support of the anti-communist regime of President Chung-hee Park, himself a nominal Buddhist. With South Korea's entrance into the Vietnam War in 1966, the MND changed its policy toward Buddhist chaplaincy as the Park administration sought to both mollify the many Buddhist conscripts being sent to war and build report with the South Vietnamese, who were predominantly Buddhist. Celebrated as a "milestone" of modern Buddhist mission work, the JO dispatched 10 Buddhist chaplains to the army (Tikhonov 2013, pp. 12-13). A military chaplaincy training institute was established within the department of Buddhist Studies in Dongguk University (K. Dongguk Daehakgyo), Korea's oldest and largest Buddhist University, as the MND finalized its rules for the selection of Buddhist chaplains, appointing the JO for their management. In 1968, five graduates from Dongguk University's chaplaincy training course were selected to enter the army's Infantry School for ten weeks of military training. Two of the five were deployed to a unit stationed in Korea, and the other three were sent to Vietnam.

By 1970, Buddhist chaplains had been officially dispatched to all branches of the military. Lacking established resources and facilities for performing their duties, this first generation of Buddhist chaplains improvised their own curriculum and methods. With support from a special council organized by the JO, temples were eventually built on-base, and the Buddhist culture slowly grew within the Korean military. However, the JO's chaplaincy program lacked the central organization of its Protestant counterparts and was operationally decades behind. A temporary office was established in Dongguk University to oversee Buddhist activities within the armed forces, resulting in the official launch of The Candidate System for Buddhist Chaplains (K. Gunbeopsa hubosaengjedo) in 1972, which was later expanded to include the order's Joong-Ang Sangha University (K. Jungang Seungga Daehakgyo). 
The program grew steadily over subsequent decades, and by the turn-of-the-millennium, the JO had been allotted almost 170 temples at various military facilities. However, the order lacked a sufficient number of chaplains to staff them, and many were supported, instead, by temples in the local community. In an effort to address these and other issues, in 2005, the order passed The Act on The Special Parish of Buddhist Chaplain, unifying all of the order's military temples and chaplains under the management of a single "Special Military Parish" (K. Gunjong Teukbyeol Gyogu). In addition to standardizing the religious education and services offered by JO chaplains, the movement sought to bring JO chaplains back under the order's control and reinforce their identity as Buddhist monastics.

The JO's chaplaincy program underwent further revisions in 2014. Following several deadly incidents of bullying and retaliation, the military's wider chaplaincy program shifted emphasis to character training and psychological counseling for soldiers in an effort to reduce "deadly emergencies" and "illicit violence" (Tikhonov 2015, p. 20). The JO's Special Military Parish made the radical decision to introduce female monastics as military chaplains, believing their efforts at counseling and consoling traumatized soldiers would be more effective. On June 27th 2014, the Korean Army formally commissioned a JO biguni as its first female chaplain (Buddha TV 2014; Kang 2014). Despite an initially negative reaction from her Protestant peers, her chaplaincy has been widely supported by her constituents, and additional female monastics were deployed as chaplains in the Navy in 2016 and the Air Force in 2017 (Ji and Baek 2009; Ha 2015). This first wave of female Buddhist chaplains has been popularly seen as positive examples of gender equality in the otherwise conservative, male-dominated JO. March 17th, 2019, saw the unveiling of a monument commemorating the 50th anniversary of the Buddhist chaplaincy program attended by JO representatives and the Army Chief of Staff.

\section{Celibacy and Buddhist Military Chaplaincy}

As surveyed above, the practice of celibacy has become the cornerstone of the JO's identity and claim to legitimacy during and after the Purification Movement (see Section 2). However, in its urgency to establish a chaplaincy program to counter Protestant proselytization efforts within the military, the JO initially granted a degree of leniency to chaplaincy candidates, as two of its first five chaplains in 1968 were married prior to deployment. Despite the issue's sensitivity, particularly after the secession of married monastics to form the rival Taego Order, the JO continued permitting its chaplains to marry, in part, to bolster recruitment and better allow its chaplains to integrate into military culture. ${ }^{4}$ In 1980 , the JO administration formally passed a marriage exception clause in the order's constitution for military chaplains. However, this decision remained a continuous source of controversy within the order as chaplains were regarded as inferior, morally suspect, and as having dubious loyalties by many of the order's celibate monastics. Furthermore, chaplains who had married were expected to renounce their monastic status following their discharge, leading many to subsequently join the rival orders, such as the Taego and Cheontae Orders, ${ }^{5}$ that permitted clerical marriage.

Through the following decades the marriage of JO chaplains became normalized, and even expected, by candidates entering the order's chaplaincy training program. However, as the JO's claim to legitimacy is predicated on monastic celibacy, this contradiction gradually became a liability for the order. Rival Buddhist orders began to challenge the JO's monopoly on the Buddhist chaplaincy program, arguing that if JO's own chaplains were permitted to marry, there was no justification for their exclusion from the program. Immersed in military life with culture and values often distant from those of the order's temples, many JO chaplains showed additional ambiguities over their dual roles, often viewing themselves first and foremost as military officers and Buddhist monastics second.

4 JO chaplains are tacitly permitted to violate monastic prohibitions against drinking alcohol and eating meat when expected to do so socially by their military superiors. However, these precept violations are not regarded as serious, nor do they challenge the core identity and ideology of the order.

5 Claiming approximately two million adherents, South Korea's Cheontae Order (K. Cheontaejong) is a separate order following the teachings and practices of the East-Asian Tientai Buddhist tradition. 
After establishing the "Special Military Parish" in 2005 in an effort, in part, to address these problems, the JO finally revoked the marriage exception for its military chaplains in 2009. In a nearly unanimous decision, the JO Central Assembly voted to amend article 9.2 of its constitution banning future marriages (Park 2009; Shin 2009), which Tikhonov describes as a "sign" of the order "recovering its sovereignty over the disputed bodies of its half-monastic half-military" chaplains (Tikhonov 2015, p. 12). Rather than settling the issue, however, the reversal sparked further controversy. Current chaplaincy candidates were thrown into confusion by the sudden decision, with some dropping out, others marrying in secret, and one even canceling his engagement (Park 2019). Although the resolution permitted the 58 already-married chaplains to retain their positions, critics charged that the new regulation would undermine their work as JO representatives, while the chaplains, themselves, complained they were not adequately consulted prior to the resolution nor given any grace period before its implementation. However, these complaints were summarily dismissed by JO authorities, who replied simply that married monastics were a threat to the order (Park 2019).

The JO's 2009 reversal of the marriage exception for its chaplains instigated further challenges to its chaplaincy program over the following decade. In 2017, two former JO chaplains brought unprecedented lawsuits against South Korea's MND for unfair dismissal following their discharge for violating the order's prohibitions against marriage. In the first case, a Navy chaplain who was married in 2011 won both his original suit and appeal, claiming that he had been married to his common-law wife prior to the passing of the 2009 resolution, but had been delayed in filing the paperwork due to deployment overseas. Not wanting to appear to interfere in religious affairs, the military had typically deferred to the decisions of overseeing religious organizations if they sought the dismissal of affiliated chaplains for ethics violations. However, the court's ruling forced the Navy to reinstate the major to his former rank, denying the JO ultimate authority over his removal. Since he had preordained with a different sect following his dismissal, however, he was relegated to an administrative position in the Navy's chaplaincy program as military regulations permitted only JO monastics to serve as active chaplains.

In the second case, a JO Air Force chaplain had married in 2014 and was summarily dismissed from the order the following year. The former chaplain reordained with the Taego Order and, following his discharge in 2017, he too filed suit against the MND to be reinstated to his former rank. However, he lost the case as he was in clear violation of established JO regulations at the time of his marriage. While the court's decision reinforced the JO's authority over its own chaplains, the former Air Force chaplain then filed a formal complaint with the National Human Rights Commission of Korea, challenging the JO's monopoly over the military's Buddhist chaplaincy program. Noting that the Cheontae Order had applied to participate in the chaplaincy program in 2014 and was denied (Gong 2014), the commission sided in favor of the ex-chaplain, criticizing the JO for "excessively monopolizing the system of Buddhist chaplaincy." Citing the diversity of the Protestant organization participating in the chaplaincy program, the commission further charged that the exclusion of "other (Buddhist) sects, is an infringement of the right to equality without any rational reason." ${ }^{6}$ The MND has agreed to accept the committee's recommendations (Lee 2019b).

In March 2019, the JO's official newspaper, the Bulgyo Sinmun, ran a series of special reports on the order's chaplaincy program which directly addressed the marriage issue. The article praised the order's 2009 reversal of the marriage exception for finally resolving the controversy, observing that only 17 of the JO's 132 acting chaplains were currently married. As these chaplains were all senior officers who would be discharged within five years, the marriage issue would soon be moot. The article did note that the JO is still struggling to fill their 170 chaplaincy positions allotted by the government. While the order had hoped its 2009 resolution would bolster recruitment by elevating the status of its

6 (Recommendations of the National Human Rights Commission 2018). 
chaplains, the number of applicants only continued to decline; a fact which the article attributed to the overall drop in monastic recruits over recent decades rather than the reversal of marriage exception. ${ }^{7}$

Despite the claims of the Bulgyo Sinmun article, the issue of married monastics serving as Buddhist chaplains is not yet settled. The same month, a private Buddhist newspaper, the Hyundae Bulgyo, published a front-page story on the lawsuit brought by the former Navy chaplain, reporting the High Court's ruling that the MND allow married monastics to serve as Buddhist chaplains (Noh and Yoon 2019). This ruling would likely prompt further controversy as it not only denies the JO ultimate authority over the military's Buddhist chaplaincy program, and could raise questions over who is ultimately responsible for the dismissal of any of the military's chaplains. Possibly, the ruling further challenges the JO's monopoly over Buddhist chaplaincy position and would likely bolster efforts by the Taego Order, Cheontae Orders, and other Buddhist sects to send their own chaplains to South Korea's armed forces (Noh and Yoon 2019).

However, the decision of the National Human Rights Commission of Korea above was overturned. In December 2019, South Korea's Supreme Court issued the final ruling on the case of the former Navy chaplain. The Supreme Court ultimately ruled against reinstating the former Navy chaplain, noting that he was well aware of the JO resolution in 2009 prohibiting the marriage of its chaplains which he violated regardless, justifying his dismissal from both the JO and the military. ${ }^{8}$

\section{Conclusions}

Since its origins in the Purification Movement of the 1950s, the Jogye Order has established monastic celibacy as central to its claim as the legitimate heir of Korean Buddhism's historical mainstream. However, in the order's hurry to enter the military's chaplaincy program after almost two decades of Protestant domination, the JO permitted its chaplains to marry; a practice which soon became the norm. This contradiction grew increasingly problematic as the order's celibate monastics came to regard chaplains inferior, while the chaplains, themselves, displayed ambiguity over their dual roles and institutional loyalties. Furthermore, rival Buddhist sects utilized this marriage exception to challenge the JO's monopoly over the Buddhist chaplaincy program. The JO attempted to finally resolve the issue by reversing the marriage exception for chaplains in 2009, prohibiting all future chaplaincy candidates from marrying. While controversial, the resolution has proved effective in practice as all remaining married chaplains will have aged out of military service by 2025 .

Many saw the JO's reversal of the marriage exception for its chaplains as a re-establishment of the order's authority over its own monastics, ending any ambiguities over the roles and loyalties of its chaplains. However, this reversal has, in fact, produced further challenges to the order's chaplaincy program by some chaplains, and a complaint was filed with the country's Human Rights Commission. The subsequent court rulings and committee recommendations had implications, not just for the JO's chaplaincy program, but for all chaplains within South Korea's armed forces. While the court's decisions have supported the prerogative of participating religious organizations to establish and enforce behavioral standards for their chaplains, the courts have also reaffirmed the military as the final authority in the hiring and firing of all military personnel. While these rulings have helped clarify the intersecting roles of South Korea's military chaplains, they have done little to parse the ambiguities created by the government guaranteeing religious freedom while simultaneously granting privileged chaplaincy positions to only a select number of religious organizations. The recommendations of the National Human Rights Commission of Korea, on the other hand, have directly challenged the JO's exclusive control of the Buddhist chaplaincy program. Given that the MND has accepted the committee's recommendations, and that the order has filled only 132 of the 170 chaplaincy positions allotted to Buddhists, it is likely that the Taego Order, Choentae Order, and others will begin submitting

\footnotetext{
(Park 2019). See (Kim et al. 2019) regarding the drop in monastic recruitment over recent decades. (Supreme Court Decision December 27th 2019), p. 7.
} 
their own chaplains to the military in the near future. It is unknown what effect this increased competition from other Buddhist sects will have on the JO's proselytization efforts in the military. However, the contradictions created by the order's own efforts to navigate the realpolitik of Korea's competitive religious marketplace during the five decades of its chaplaincy program might ultimately cause the order to lose its privileged monopoly over Buddhist life within the military. Given these future challenges, it is not unthinkable that the JO might reverse its position yet again, allowing its chaplains to marry in another effort to boost recruitment to counter religious competition, this time from other Buddhist sects. Nevertheless, due to the final decision of the Supreme Court in 2019, the JO could maintain the exclusive control of the chaplaincy program for the time being and gained time to respond to these external challenges.

Author Contributions: Supervision, C.P.; Writing—original draft, K.K.; Writing-review \& editing, K.K. and C.P. All authors have read and agreed to the published version of the manuscript.

Funding: This research received no external funding.

Conflicts of Interest: The authors declare no conflict of interest.

\section{References}

Brinsfield, John W. 2009. The U.S. military chaplaincy, then and now. The Review of Faith E International Affairs 7: $17-24$.

Buddha TV. 2014. Available online: http://www.buddhatv.com/bbs/board_view.asp?pk_idx=692\&b_budle=news (accessed on 27 March 2020). (In Korean).

Buswell, Robert E., Jr. 1992. The Zen Monastic Experience: Buddhist Practice in Contemporary Korea. Princeton: Princeton University Press.

Buswell, Robert E., Jr. 1996. Available online: http://www.buddhism.org/is-celibacy-anachronistic (accessed on 30 March 2020).

Gong, Tae-sun. 2014. Bulgyojeoneol. Available online: http://www.buddhismjournal.com/news/articleView.html? idxno=10961 (accessed on 20 March 2020). (In Korean).

Ha, Jonghun. 2015. Seoul Sinmun. Available online: http://www.seoul.co.kr/news/newsView.php?id= 20150627021034 (accessed on 20 March 2020). (In Korean).

Ham, Hyun-Chun. 2016. Retrospect and prospects of the Buddhist missionary work. Literature History Philosophy 45: 160-75. (In Korean).

Ji, Hoil, and Sanghyun Baek. 2009. Kookmin Ilbo. Available online: http://news.kmib.co.kr/article/view.asp?arcid= 0001357880 (accessed on 20 March 2020). (In Korean).

Jogye Order. 2018. The 50 Year History of the Buddhist Chaplain Service. Seoul: The Jogye Order. (In Korean)

Kang, In-Cheol. 2000. Buddhism and state in post-liberation. Society and History 57: 79-112. (In Korean).

Kang, Juhyung. 2014. Hankook Ilbo. Available online: http://m.hankookilbo.com/news/read/201406302079947838? backAd=1 (accessed on 17 March 2020). (In Korean).

Kang, In-Cheol. 2015. Critical reflections on the studies of Korean military chaplaincy. Jonggyo Yeongu 75.4: 175-204. (In Korean).

Kang, In-Cheol. 2016. Critical reflections on the organization and activities of Korean military chaplaincy. Jonggyo Yeongu 76.4: 65-95. (In Korean).

Kim, Chang Mo. 2007. Buddhist military mission: Results and questions. Seon Munhwa Yeongu 3: 131-75. (In Korean).

Kim, Kyungrae, Eunyoung Kim, Wangmo Seo, and Chenghwan Park. 2019. Some Contemporary Dilemmas of Korean Buddhism: A Critical Review of the Jogye Order's 2018 Periodic Report. Religions 10: 234. [CrossRef]

Lee, Byungdoo. 2019a. Beopbo Sinmun. Available online: https://www.beopbo.com/news/articleView.html?idxno= 205989 (accessed on 5 March 2020). (In Korean).

Lee, Changyun. 2019b. Bulgyo 21. Available online: http://m.bulkyo21.com/news/articleView.html?idxno=42475 (accessed on 7 March 2020). (In Korean).

Ministry of National Defense. 2016a. Edict on the Service of Military Chaplains; No.1879; Seoul: Ministry of National Defense.

Ministry of National Defense. 2016b. Defense Order; No.907; Seoul: Ministry of National Defense. 
Mun, Chanju. 2011. Purification Buddhist Movement, 1954-1970: The struggle to restore celibacy in the Jogye Order of Korean Buddhism. Honolulu: Blue Pine.

Noh, Duk-hyun, and Ho-Seop Yoon. 2019. Hyundaebulgyo. Available online: http://www.hyunbulnews.com/news/ articleView.html?idxno=299288 (accessed on 7 March 2020). (In Korean).

Park, Pori. 2007. The Buddhist Purification Movement in postcolonial South Korea: Restoring clerical celibacy and state intervention. In Identity Conflicts: Can Violence be Regulated? Edited by Craig J. Jenkins and Esther E. Gottlieb. London: Transaction Publishers, pp. 131-45.

Park, Bongyoung. 2009. Bulgyo21. Available online: http://www.bulkyo21.com/news/articleView.html?idxno=6315 (accessed on 17 March 2020). (In Korean).

Park, Booyoung. 2019. Bulgyo Sinmun. Available online: http://www.ibulgyo.com/news/articleView.html?idxno= 172660 (accessed on 7 March 2020). (In Korean).

Recommendations of the National Human Rights Commission. 2018. Available online: https://www.humanrights. go.kr/site/program/board/basicboard/view?menuid=001004002001\&searchselect=boarddesc\& searchword=\%EC $\%$ A1 $\%$ B0 $\%$ EA $\%$ B3\%84\%EC \%A2\%85\&pagesize=10\&boardtypeid=24\&boardid=7603656 (accessed on 30 March 2020). (In Korean).

Supreme Court Decision December 27th. 2019. Available online: https://www.scourt.go.kr/supreme/news/ NewsViewAction2. work? seqnum $=6940 \&$ gubun $=4 \&$ searchOption $=\&$ searchWord $=($ accessed on 30 March 2020). (In Korean).

Shin, Hyukjin. 2009. Bulgyofocus. Available online: http://m.bulgyofocus.net/news/articleView.html?idxno=56662 (accessed on 17 March 2020). (In Korean).

Tikhonov, Vladimir. 2010. The Japanese missionaries and their impact on Korean Buddhist developments (1876-1910). In Makers of Modern Korean Buddhism. Edited by Jin Y. Park. Albany: State University of New York Press.

Tikhonov, Vladimir. 2013. South Korea's Christian military chaplaincy in the Korean War-Religion as ideology? The Asia-Pacific Journal 11: 1-16.

Tikhonov, Vladimir. 2015. Militarized masculinity with Buddhist characteristics: Buddhist chaplains and their role in the South Korean Army. The Review of Korean Studies 18: 8-33.

Waggoner, Edward. 2019. Religion in Uniform: A Critique of US Military Chaplaincy. New York: Lexington Books.

(C) 2020 by the authors. Licensee MDPI, Basel, Switzerland. This article is an open access article distributed under the terms and conditions of the Creative Commons Attribution (CC BY) license (http://creativecommons.org/licenses/by/4.0/). 